\title{
Sor María de Ágreda y la vida cotidiana en Ágreda en el siglo XVII: una aproximación histórica
}

\author{
Ana MorTe Acín \\ Queen Mary University (Londres) \\ anamorte@yahoo.com
}

Recibido: 18 de febrero de 2011

Aceptado: 3 de febrero de 2013

\section{RESUMEN}

Debido a su fama de santidad, Sor María de Ágreda se convirtió en una figura de referencia para la población de Ágreda y sus alrededores, que acudía a ella en busca de consejo, ayuda y en algunos casos para pedirle que actuara como mediadora de sus conflictos familiares. A través de estos testimonios nos adentramos, por un lado, en la vida cotidiana de Ágreda en el siglo XVII y, por otro, en el tema de la autoridad femenina. Autoridad de la que se revistieron algunas mujeres veneradas como santas durante el Barroco hispánico y que les permitió tener además reputación de sabias en sus comunidades.

Palabras clave: Sor María de Ágreda, vida cotidiana, autoridad femenina, religiosidad barroca.

\section{Sor María de Ágreda and everyday life in Ágreda in 17th Century: a historical approach}

\begin{abstract}
Due to her saintly reputation, Sor María de Ágreda became a reference figure for the population of Ágreda and its environs who came to her for advice, assistance and in some cases to ask her to act as a mediator of family conflict. Through these testimonies we enter on the one hand, in the daily life of Ágreda in the seventeenth century and secondly, on the topic of female authority. Authority that some women were coated venerated as saints during the Baroque Hispanic and which gave them reputation wise.
\end{abstract}

Key words: Sor María de Agreda, daily life, female authority, Baroque religiosity.

Sor María de Ágreda es una de las figuras más relevantes del Barroco hispánico, aunque, en realidad, de ella ha llegado hasta nosotros una imagen que responde, en 
buena medida, a un estereotipo forjado a lo largo del tiempo ${ }^{1}$. Nació el 2 de abril de 1602 en el seno de una familia formada por Francisco Coronel, Catalina de Arana y sus hijos José, Francisco, Gerónima y María de Jesús, la futura Sor María de Ágreda².

Según su propio relato, cuando ya era una mujer madura, Catalina de Arana recibió el mandato divino de que toda su familia entrara en religión y que convirtiera su casa en un convento. El proyecto, pese a las dificultades, se llevó a cabo y en 1619 Catalina y sus dos hijas entraron en el convento de la Concepción de Ágreda. A partir de entonces el relato de la vida de Sor María está lleno de sucesos de carácter sobrenatural: arrobos, éxtasis místicos, curaciones, etc. muy comunes, por otro lado, en las abundantes biografías y autobiografías de religiosas del siglo XVII hispánico ${ }^{3}$. Entre todas estas experiencias cabe destacar, especialmente, la supuesta bilocación de Sor María en América, adonde se trasladaba a catequizar indios sin abandonar mientras su convento de Ágreda. Hecho controvertido por el que se interesó la Inquisición años después. ${ }^{4}$ Pero, sin duda, el hecho que marcó la trayectoria de Sor María fue la visita de Felipe IV a Ágreda en su camino al frente de Cataluña en el verano de

1 Algunas de las obras que se han escrito sobre Sor María son: Silvela, F.: "Bosquejo histórico" a las Cartas de la Venerable Madre Sor María de Ágreda y del Señor Rey Felipe IV, Madrid, Suc. De Rivadeneyra, 1885 (2 vol.); Seco Serrano, C.: Cartas de Sor María de Jesús de Agreda y de Felipe IV, B.A.E. 108 y 109, Madrid, Atlas, 1958 (2 vols.), que contiene dos obras muy importantes: Tratados autobiográficos de la Madre Ágreda (vol. 2, págs. 205-230) y Vida de Sor María de Ágreda narrada por el padre José Ximénez de Samaniego como "Prólogo Galeato" a la Mística Ciudad de Dios, (vol. 2, págs. 269-385); Baranda Leturio, C.(ed.): María Jesús de Ágreda, Correspondencia con Felipe IV. Religión y Razón de Estado, Madrid, Castalia, 1991; BRINGAS y ENCINAR, D.: Índice apologético de las razones que recomiendan la obra intitulada "Mistica Ciudad de Dios"..., Valencia, 1834 y Admirable vida y ejemplarisimas virtudes..., Santiago, 1884; Sánchez Toca, J.: Felipe IV y Sor María de Ágreda, Madrid, 1887; Torrente Ballester, G.: María de Jesús de Ágreda (1602-1665), Madrid, Ediciones Fe, 1942; Moreno y Moreno, M.: Crónica del III Centenario de la muerte de Sor María de Jesús de Ágreda, Soria, Tall.Urbion, 1966; Moral, B.: Más almas marianas: V. María de Ágreda..., Madrid, Sociedad de Educación Atenas,1956; Royo CAmpos, Z.: Mi mejor ofrenda: en el tricentenario de... Sor María de Jesús de Ágreda, Granada, Imp. Anel, 1966; Ximénez SAndoval, F.: Un mundo en una celda, Madrid, Studium de Cultura, 1951; Royo, E.: Autenticidad de la Mistica Ciudad de Dios y biografia de su autora, Barcelona, Herederos de Juan Gil, 1914; García Royo, L.: "La Madre Ágreda entre los indios de Texas" en Celtiberia, 15, (1965); ID.: La aristocracia española y Sor María de Jesús de Ágreda, Madrid, Espasa-Calpe,1951; ID.: Lirio en el Moncayo, Sor María de Jesús de Ágreda, Logroño, Gráficas Cantabria, 1946, VV.AA., La Madre Ágreda una mujer del siglo XXI, Soria, Universidad Internacional Alfonso VIII, 2000; El papel de Sor María de Jesús de Ágreda en el Barroco español, Soria, Universidad Internacional Alfonso VIII, 2002; CАBIBBo, S.: "Il "“libro serrado' di Maria d'Agreda. Per un'analisi della cultura biblica femminile nella Spagna del Seicento", en Leonardi, C. y VALERIO, A. (dirs.): La Bibbia nell'interpretazione delle donne, Florencia, SISMEL edizioni del Galluzzo, 2003, pp. 87-105; CABIBBo, S.:"Una "dama niña y hermosa" nella Nuova Spagna. Maria d'Agreda fra gl'Indios", en ZARRI, G., (dir.): Ordini religiosi, santità e culti: prospettive di ricerca tra Europa e America Latina, Lecce, Congedo Editore, 2003, pp. 111-27, MoRTE Acín, A.: Misticismo y conspiración: Sor María de Ágreda en el reinado de Felipe IV, Zaragoza, I.F.C., 2010.

2 Estos datos biográficos de Sor María de pueden ver en: Silvela, op. cit. (nota 1); Seco Serrano, op. cit. (nota 1) y BARANDA LeTURIO, op. cit. (nota 1).

3 Sobre religiosidad femenina se pueden consultar, entre otros: SÁnchez LoRA, J. L.: Mujeres, conventos y formas de religiosidad barroca, Madrid, F.U.E., 1988; Poutrin, I.: Le voile et la plume. Autobiographie et sainteté feminine dans l'Espagne moderne, Madrid, Casa de Velázquez, 1995.

4 Sobre la bilocación se puede ver: Borges Morán, P.: "La controvertida presencia de la M. Ágreda en Texas (1627-1630)" en La Madre Ágreda una mujer del siglo XXI, op. cit. (nota 1); OMAECHEVARRía, I.: "Un ejemplo maravilloso de contemplación misionera: sor María de Jesús de Ágreda”, en Misionalia Hispanica, 10, (1953); Donahue, W. H.: "Mary of Ágreda and the Southwest United States", en The Americas, 9, (1953) y GARCIA RoYo, op. cit. (nota 1, 1965). 
1643. A partir de entonces comenzó una correspondencia que duró 22 años y que es uno de los aspectos más conocidos y analizados de la vida de la agredana. También importante fue su faceta de escritora. Su obra cumbre, La Mística Ciudad de Dios, una biografía de la Virgen María, suscitó una enorme polémica cuando fue publicada en 1670 , cinco años después de la muerte de su autora ${ }^{5}$.

Así, la imagen que ha llegado a nosotros de Sor María de Ágreda se sustenta en tres pilares: sus experiencias sobrenaturales, destacando entre ellas la bilocación, su correspondencia con Felipe IV y su supuesto papel de consejera del monarca en asuntos políticos y su obra La Mística Ciudad de Dios.

Uno de los elementos clave a la hora de entender la formación de esa imagen de Sor María es precisamente la opinión que sobre ella tuvieron sus contemporáneos y que se fue transmitiendo a través de los años. Como otros religiosos de la época, tras su muerte, comenzó el proceso para alcanzar su beatificación. En él se llevó a cabo un interrogatorio en el que participaron muchas personas que la conocieron y que mantuvieron un trato muy cercano con ella. A pesar de que una de las imágenes que más se asocian con la figura de Sor María es su relación con las altas esferas de la monarquía, hay que destacar que no fueron sus miembros los que declararon mayoritariamente en el proceso, sino las gentes de Ágreda y sus alrededores que poco o nada tenían que ver con la Corte.

La fuente principal de la que nos hemos servido para elaborar este trabajo es el expediente del proceso ordinario de beatificación que incluye un interrogatorio exhaustivo a los testigos sobre la vida y obra de Sor María. Se trata, por tanto, de una fuente compuesta por testimonios, bajo juramento, ante un notario, encaminados a demostrar la santidad de una persona. El interrogatorio consistió en 95 preguntas que abarcaban todos los aspectos de la vida de Sor María. Las primeras preguntas versaban sobre la identidad del deponente y de la relación de éste con la religiosa. Había preguntas dedicadas a los supuestos prodigios protagonizados por Sor María como la bilocación o las curaciones milagrosas. También se les preguntaba a los testigos por las virtudes de la agredana, pidiendo que declarasen todos lo ejemplos que sirvieran para ilustrar cada una de las aseveraciones que hacían y, por supuesto, también había preguntas dedicadas a la relación de Sor María con Felipe IV. Testificaron 64 personas, entre los que se encuentran individuos de toda condición, pero sobre todo, abundan los pertenecientes a la población de Ágreda.

A pesar de sus limitaciones, nos parece una fuente muy útil a la hora de reconstruir las relaciones de Sor María con la población de Ágreda y a través de esa relación hacer un esbozo de algunos aspectos de la vida cotidiana de la villa (aspecto este olvidado generalmente en las obras dedicadas a Sor María, pero que nos permitirá una mejor comprensión de su figura). Ese es el objetivo de este artículo.

Este tipo de fuente, poco utilizado hasta el momento, nos ha sido de utilidad principalmente por dos motivos. En primer lugar, porque aporta una serie de datos sobre las personas que conocieron o rodearon al sujeto objeto de la investigación, en este

5 De la problemática de La Mística Ciudad de Dios ver: Artola, A.: “La 'Mística Ciudad de Dios' en la Sorbona. Un conflicto teológico a nivel europeo", en El papel de Sor María de Jesús de Ágreda en al Barroco español, op. cit. (nota 1), p. 195 y VÁzQuez Janeiro, I.: "La Mística Ciudad de Dios de la Madre Ágreda de censura en censura", en La Madre Ágreda una mujer del siglo XXI, op. cit. (nota 1), pp. 120-121. 
caso Sor María, aspecto sobre el que habitualmente es difícil obtener información, dado que en las biografías o hagiografías se hace un relato idealizado de la vida de la persona y se suelen obviar datos de su vida cotidiana y su entorno. En segundo lugar, porque al tratarse de un proceso en el que deben ponerse de manifiesto las virtudes y prodigios atribuidos al sujeto, los testigos relatan episodios de su vida cotidiana con abundancia de detalles para ilustrar y subrayar la intervención de la persona a favor de la que testifican. Es, precisamente, entre esa cantidad de ejemplos, detalles y datos, donde se puede hallar información de interés, ya que, por norma, es en la resolución del caso narrado donde se exaltan las virtudes del individuo (y por tanto es la parte del testimonio más susceptible de ser manipulada o exagerada), pero no tanto en la explicación de las circunstancias en las que se lleva a cabo su intervención. En cualquier caso, se trata de una fuente con un componente fuertemente subjetivo, dado el objeto de la misma, y por tanto, se hace necesaria en el tratamiento de la información una labor de crítica minuciosa.

En el siglo XVII Ágreda era una villa habitada mayoritariamente por agricultores y todo el entorno de la misma, salvo Tarazona, era una zona rural ${ }^{6}$. A juzgar por la documentación, Sor María se convirtió en una persona de referencia para la población. Existió un constante ir y venir al convento para visitarla, en muchos casos, en busca de consejo, ayuda o consuelo. En otros, por el simple hecho de estar en contacto con ella, y es que, en Ágreda, todos sabían de la historia de la joven monja con fama de santa, conocían a su familia y habían vivido de cerca su trayectoria.

La mayor parte de los testigos centraron su testimonio en las preguntas referidas a las curaciones o las intervenciones de carácter milagroso supuestamente llevadas a cabo por Sor María, y no tanto en las referidas a cuestiones teológicas. Es, precisamente, en el relato de las situaciones conflictivas en las que Sor María intervino en donde encontramos la información útil a nuestro propósito. Problemas relacionados con la violencia presente en la sociedad: asaltos, agresiones, etc. Problemas dentro del seno familiar, fundamentalmente de violencia doméstica y problemas de salud y adicciones, son los que con más recurrencia aparecen en la documentación.

La familia Castejón, la más poderosa de Ágreda, y cuyo palacio aún puede contemplarse en la actualidad, mantuvo una estrecha relación tanto con Sor María como con el convento, lo que se puso de manifiesto en el Proceso. Los miembros de esta familia ocuparon sistemáticamente cargos en el organigrama municipal tanto de Ágreda como de Tarazona, localidad de procedencia o residencia de algunos de ellos. Varias mujeres de esta familia entraron como religiosas al convento y, además, la congregación recibió de ellos cuantiosos donativos. En el Proceso testifican 10 personas de la familia Castejón aunque pertenecientes a diferentes ramas?

\footnotetext{
6 Sobre Ágreda en tiempos de Sor María se pueden obtener algunos datos en: Rubio SEmPER, A.: "Ágreda en el siglo XVII", en El papel de Sor María de Ágreda en el Barroco español, op. cit. (nota 1), pp. 43-61.

7 Los testigos pertenecientes a esta familia son: Dña. María Méndez de Sotomayor, viuda de D. Diego Ruiz de Castejón, sus dos hijas, Sor Michaela María de los Reyes y Sor Polonia María del Santísimo Sacramento. Dña. Isabel de Blancas, mujer de D. Juan de Castejón, cuñada de Dña. María Méndez. Sor Petronila María de San José, en el siglo Dña. Petronila Josepha de Castejón y Fuenmayor y su hermano D. Agustín de Castejón y Fuenmayor, caballero de la Orden de Santiago. D. Martín Pedro Castejón, Señor de Belamazán, caballero de la Orden de Calatrava y su mujer Dña. Teresa Ibañez. Sor Inés María de Jesús, en el siglo, Dña. Inés María de
} 
Los testimonios, como no es de extrañar, son muy desiguales y no aportan información en la misma medida, por lo que he seleccionado sólo algunos de ellos, los que resultan más ilustrativos. En primer lugar, destaca Doña María Méndez de Sotomayor ${ }^{8}$, viuda de D. Diego Ruiz de Castejón, natural de Madrid de 84 años de edad, y dos de sus hijas, religiosas en el convento, Sor Michaela María de los Reyes ${ }^{9}$, en el siglo Doña Michaela Ruiz de Castejón, natural de Tarazona de 53 años y Sor Polonia María del Santísimo Sacramento ${ }^{10}$, en el siglo, Doña Polonia Ruiz de Castejón, natural de Tarazona de 47 años de edad. Aún entró como religiosa otra hija más de Doña María, según su declaración, pero el testimonio de esta tercera hija no aparece en el proceso, por causas que se desconocen.

De estos tres testimonios, sin duda, el más interesante es el de la madre, Doña María Méndez, ya que debido a su avanzada edad había conocido a Sor María desde que era una niña, mucho antes incluso de que entrara en el convento. En su declaración se trasluce la relación de amistad que mantuvo con la religiosa, a la que visitaba con frecuencia en el convento, primero para verla a ella y más adelante para visitar también a sus hijas ${ }^{11}$.

Doña María da fe a lo largo de su testimonio de la veracidad y fama pública de los episodios más conocidos de la vida de Sor María. La intervención divina en la fundación del convento en su propia casa, los arrobos en su juventud, de los que ella misma había sido testigo, y de diversas curaciones milagrosas que la divinidad había obrado por medio de la abadesa y de las que ella también se había beneficiado. En concreto, cuenta cómo estando embarazada de cuatro meses y medio, sufrió dolores y sangrados, asegurándole los médicos que el niño estaría muerto y gracias a un cordoncillo que le entregaron de parte de Sor María, que entonces aún no era abadesa, cesaron los dolores y el niño nació con normalidad. Además, la cercanía con la que trató a Sor María y la frecuencia con la que visitaba el convento le permitieron estar al corriente de todo lo que sucedía dentro de sus muros.

También de la familia Castejón testificaron Don Martín Pedro Castejón, Señor de Belamazán, Caballero del hábito de Calatrava, natural y vecino de Ágreda de 33 años de edad ${ }^{12}$ y su mujer, Doña Teresa Ibáñez, natural de Bilbao, de 29 años de edad ${ }^{13}$. Doña Teresa también recibió ayuda de Sor María para superar unos problemas de salud surgidos tras un parto, que puesto que era un momento crítico en la vida de toda mujer de la época, por las complicaciones médicas que frecuentemente se derivaban

Castejón y Velnio y Don Miguel Pasquier de Camargo, Caballero de la Orden de Santiago, Justicia perpetuo de la ciudad de Tudela y Regidor de la villa de Ágreda, hijo de Dña. Francisca de Castejón.

8 Archivio Segreto Vaticano (ASV), Congr. Riti, Proc. 3206, testimonio de Dña. María Méndez de Sotomayor, f.18rv.

9 Ibidem, f. $160 \mathrm{v}-162 \mathrm{r}$.

10 Ibidem, f. 162r-165v.

11 ASV, Congr. Riti Proc., 3206: Cuenta cómo se desarrollaban estas visitas, comunicándose con ella a través del torno, siendo la tornera en aquellos momentos la propia madre de Sor María, Catalina de Arana, en religión Sor Catalina del Santísimo Sacramento, lo que le permitía estar al corriente de las visitas que recibía su hija. f. $18 \mathrm{v}$.

12 ASV, Congr. Riti. Proc. 3206, f.40r-v.

13 Ibidem, f.339v-341r. 
de él, aparece recurrentemente en los testimonios como uno de los momentos en que los que con más frecuencia se imploraba la intercesión de Sor María ${ }^{14}$.

Sin embargo, buena parte de la información más interesante que nos ofrecen estos testimonios nos llega a través de lo que a Doña Teresa le había contado una criada suya, Mariana Ruiz, que conocía a Sor María desde niña, y que como Doña Teresa afirma "era criada de antiguo de la casa de mi marido". En efecto, la familia de Mariana Ruiz era vecina de la de Sor María, vivían "pared en medio de su casa". Lo que Mariana Ruiz relató a su señora Doña Teresa, nos permite saber que las relaciones entre la familia de Sor María y sus vecinos fue cordial, al menos durante la infancia de la pequeña, cuya precoz manifestación de sus supuestos dones divinos no pasó inadvertida para la vecindad.

Según este testimonio, ya desde muy niña se hizo visible que "gozaba de especialísimos favores y gracias", y cuando Catalina dejaba al cuidado de su hija a su vecina Mariana Ruiz, le había advertido de la facilidad que la niña tenía para "arrobarse" y que, en caso de que le ocurriese, la metiese en casa para que no la pudieran ver en ese estado otras personas. Estando un día con la pequeña María haciendo labor, pasó por delante de su puerta el Santísimo Sacramento, porque lo llevaban a casa de un enfermo, y nada más verlo Mariana Ruiz se percató de que, efectivamente, la niña al arrodillarse para adorar el paso del Santísimo, se había quedado "arrobada", por lo que siguiendo las instrucciones de su madre la cogió en brazos y la metió dentro de la $\operatorname{casa}^{15}$. Así pues, desde pequeña era conocido por sus vecinos que la pequeña María Coronel era una niña especial.

Don Miguel Pasquier de Camargo, caballero de la Orden de Santiago, Justicia perpetuo de la Ciudad de Tudela, Regidor perpetuo de la villa de Ágreda, natural y vecino de ella de 74 de años de edad, es otro de los "Castejones" del que nos vamos a ocupar. Era hijo del Dr. Don Jerónimo de Camargo del Consejo de su Majestad y oidor en la Real Chancillería de Valladolid y de Dña. Francisca de Castejón, ambos naturales de la villa de Ágreda. Había pasado muchos años fuera de Ágreda al servicio del Rey desempeñando diferentes cargos, como administrador general de los millones del reino de Murcia, y posteriormente en Valladolid. Su testimonio nos ofrece abundante información sobre las visitas que Sor María recibía en el convento. En su relato recuerda que visitaron el convento el Cardenal Monti, nuncio del Papa en España, el Cardenal Camillo de Maximis, también nuncio, y el Cardenal Julio Rospillosi, que acudió dos veces a visitarla y que le escribió desde Roma aún después de ser elegido Papa $^{16}$.

14 Las complicaciones en el parto y el postparto era una de las causas frecuentes de mortalidad en las mujeres. Sobre este tema se puede ver por ejemplo: Ortega, M.: "Las edades de las mujeres", en Morant, I. (ed.): Historia de las mujeres en España y América, vol. II. El mundo moderno, Madrid, Cátedra, 2005, pp. 337-338; Bolufer Peruga, M.: "Del cuerpo violentado al cuerpo tutelado. Doctrina religiosa y discurso higiénico en el siglo XVIII: el ejemplo del nacimiento”, en JimÉnEz Morales, Ma a I. y Quiles FeZ, A. (coords.): De otras miradas: reflexiones sobre la mujer de los siglos XVII al XX, Málaga, Universidad de Málaga, 1998.

15 ASV, Congr. Riti. Proc. 3206, testimonio de Doña Teresa Ibáñez, f. 340v.

16 ASV, Congr. Riti. Proc. 3212, testimonio de D. Miguel Pasquier de Camargo, f. 39v-56r. 
También perteneciente a esta familia, fue D. Diego de Castejón ${ }^{17}$, obispo de Tarazona, con cuyo testimonio no se puede contar porque ya había fallecido cuando se inició el proceso, pero que sabemos, por otros testimonios, que jugó un papel importante en la vida de Sor María. D. Diego prestó ayuda económica durante la construcción del nuevo convento, y a pesar de ser obispo de Tarazona, residió muchos años en Ágreda, donde mantuvo un estrecho contacto con la abadesa, le ayudó a resolver algunos conflictos, como vamos a ver más adelante, y en cuyo convento celebró "las más célebres funciones Pontificias, y exequias de Reina y príncipe como diciendo (que se lo ha oído decir muchas veces) haec est domus dei et porta celi" ${ }^{18}$.

La familia Orobio, a la que pertenecía la abuela materna de Sor María ${ }^{19}$, es otra de las que contribuyeron con más testimonios al Proceso. Era también una familia pudiente de la villa, algunos de cuyos miembros residían en Tarazona, Borja o Zaragoza. Cabe destacar también el elevado número de mujeres pertenecientes a los Orobio que entraron como religiosas en el convento, lo que propició una vinculación especial de esta familia con la congregación y podría explicar el interés que mostraron por testificar en el Proceso.

Doña Ildefonsa de Orobio, natural de Ágreda de 57 años de edad, afirma que tuvo cuatro hermanas que entraron religiosas en el convento, $\mathrm{y}$ un primo hermano suyo, D. Mateo de Orobio, clérigo presbítero, también natural de Ágreda, afirma tener tres hermanas y cuatro primas monjas en el convento. Así que al menos siete mujeres de esta familia entraron a formar parte de la congregación, un número nada despreciable. En sus testimonios predominan los relatos acerca de curaciones por medio de cruces, cuentas, pañitos y otros objetos que Sor María les hacía llegar, en muchas ocasiones, a través de las religiosas de la familia que había en el convento.

Los Camargo, son la tercera familia pudiente de Ágreda que aportó testimonios al Proceso. Ya nos hemos referido a D. Miguel de Camargo y Pasquier. Contamos además con las declaraciones de Dña. Úrsula de Camargo y Pasquier y de D. Joseph Antonio de Camargo, hermana e hijo respectivamente de D. Miguel. De hecho los dos hermanos, D. Miguel y Dña. Úrsula se casaron a su vez con otros dos hermanos, Dña. Juliana Pasquier y D. Francisco Pasquier. También en el caso de los Camargo hubo mujeres de la familia que entraron como religiosas en el convento. En concreto conocemos el caso de dos de ellas. La primera una hermana de Dña. Úrsula ${ }^{20}$ y la

17 Diego de Castejón y Fonseca fue gobernador del Consejo de Castilla entre 1639 y 1643 . Fue servidor del Conde Duque de Olivares, y tras su caída fue destituido y enviado como obispo a Tarazona. Río BARREDO, Ma. J. del: Madrid. Urbs Regia. La capital ceremonial de la Monarquía Católica, Madrid, Marcial Pons Historia, 2000, p. 206.

18 ASV, Congr. Riti. Proc. 3212, testimonio de D. Francisco de Escharri, f. 21 r.

19 Los testigos pertenecientes a esta familia son: Dña. Ildefonsa de Orobio, natural de Ágreda de 57 años de edad, su marido D. Antonio Muñoz Serrano, caballero del hábito de Santiago, baile y merino de la ciudad de Tarazona y distrito, natural y vecino de Tarazona, D. Mateo de Orobio, clérigo presbítero de Ágreda de 59 años de edad, primo hermano de Ildefonsa, Sor Isabel María de los Ángeles, Dña. Isabel de Orobio en el siglo, natural de Ágreda de 58 años de edad, hermana de Ildefonsa, Sor Mariana de Jesús de Jesús, en el siglo Dña. Mariana de Orobio natural de Ágreda de 63 años de edad, Sor Teresa María de Jesús, en el siglo Dña. Teresa de Orobio y Ordoñez, natural de Ágreda de 35 años de edad, D. Joseph de Orobio, caballero natural de Ágreda de 42 años de edad y D. Marcos de Orobio, caballero natural de Ágreda de 39 años de edad, ambos presumiblemente hijos de Dña. Ildefonsa y D. Antonio Muñoz.

20 ASV, Congr. Riti. Proc. 3206, testimonio de Dña. Úrsula de Camargo y Pasquier, f. 28 rv. 
segunda, una hija de D. Miguel y Dña. Juliana, que siendo muy niña, sufrió una grave enfermedad de la que los médicos daban por seguro que iba a morir, y siendo su madre muy devota de Sor María, le ofreció que si curaba a su hija la metería monja en el convento. Así ocurrió, la niña se curó y entró en él a los once años de edad ${ }^{21}$.

Una de las personas que más estrecha relación mantuvo con Sor María fue, sin embargo, alguien que no pertenecía a ninguna de las familias anteriormente citadas. Se trata de Don Francisco Antonio de Echarri y Gandía, "presbítero arcediano de Calatayud en la Santa iglesia Catedral de Tarazona, y canónigo de dicha Santa Iglesia, que era natural y vecino de Tarazona". En el momento de testificar contaba con sesenta años aproximadamente, por lo que era tan sólo unos años más joven que Sor María. Contaba en el convento de Ágreda, además, con la presencia de dos mujeres muy especiales en su vida: su hermana Sor Atilana, gracias a la cuál entró en contacto con la abadesa, y su mujer, Sor Antonia. Tras su separación conyugal y la entrada en el convento de su mujer fue cuando comenzó su carrera eclesiástica.

Don Francisco actuó como vínculo de unión del convento con el exterior, y se ocupó, entre otras cosas, de realizar numerosas gestiones para las religiosas. Gracias al desempeño de esta labor, Don Francisco mantuvo un contacto habitual y cercano con el convento a lo largo de muchos años, lo que le permitió establecer con Sor María, con la que a la postre debía tratar sobre los asuntos de los que se ocupaba fuera del convento, una relación cercana, de confianza.

Fue, por ejemplo, Don Francisco el encargado, en 1644, de organizar el transporte desde Madrid, donde en aquellos momentos se encontraba, de la talla de la Purísima Concepción, que el Conde de Lemos envió al convento de Ágreda, y que se convirtió en una de las imágenes, la Virgen del Coro, por la que más devoción se sintió desde entonces ${ }^{22}$.

Sor María encargó también a Don Francisco que hiciera imprimir unas cuantas copias de un libro de la Regla, que conservaba en el convento, porque había pocos ejemplares, y entendía que era bueno que todas las religiosas contaran con ese libro. Así lo llevó a cabo, aunque se guardó para sí, según su testimonio, el ejemplar original, que aún tenía en su poder, y del que tenía la intención de volver a mandarlo imprimir ${ }^{23}$. También Don Francisco, a petición de Sor María, mandó que se imprimiesen copias de la Letanía de Nuestra Señora, obra de la religiosa, con el fin de poder repartirlas entre los fieles que acudiesen a visitarla ${ }^{24}$.

Por tanto, la relación entre Don Francisco y Sor María fue de confianza, y ambos se ayudaron mutuamente en sus diversas ocupaciones, estableciendo una estrecha colaboración en numerosas materias de orden práctico que propició que su relación se basara en la cotidianeidad y la resolución de problemas de carácter doméstico.

Como hemos señalado anteriormente, el propósito de este trabajo es mostrar cómo era la relación de Sor María con sus vecinos de Ágreda, las personas que le rodeaban, cómo participaba de la vida, de los acontecimientos de la villa, alejándonos de los

21 Ibidem, testimonio de D. Miguel de Camargo, f. 35r-36r.

22 ASV, Congr. Riti, Proc. 3206, testimonio de Don Francisco de Echarri, f. 23r.

23 Ibidem, f. $23 \mathrm{v}$.

24 Ibidem, f. $25 \mathrm{v}$. 
graves asuntos de estado de los que se encargaba en su correspondencia con el rey o la familia Borja ${ }^{25}$.

A la mayoría de los habitantes de Ágreda les quedaba muy lejos la corte y sus entresijos, y sus problemas y preocupaciones versaban sobre temas muy distintos. Como ya hemos podido observar al referirnos a las familias más pudientes de la villa, sin duda, el principal motivo que movía a la población a acercarse al convento eran los problemas de salud y la esperanza de poder obtener una curación milagrosa. Pero también hubo otros motivos que hicieron que algunas personas, cuyos testimonios han llegado hasta nosotros, acudieran a Sor María en busca de consuelo y ayuda, y que nos permiten atisbar una parte de la dura realidad a la que debían enfrentarse las gentes de esta época y a la que Sor María no fue ajena.

Varios de los testimonios a los que vamos a hacer referencia tienen que ver con problemas familiares de diversa índole. Aunque como decimos la fuente que manejamos adolece de ser fuertemente subjetiva, sí creemos que es reflejo de la problemática a la que debía enfrentarse la población, mostrándose esa subjetividad más en el relato de la resolución y actuación de Sor María, que en la exposición de los casos.

El matrimonio era en estos momentos una institución que cumplía con un papel fundamental, el de proveer súbditos a la Corona, pero también colaboraba con el proyecto sociopolítico de la Corona en el que la jerarquía y el orden social, también en su vertiente sexual, jugaban un papel fundamental. Se trataba de un pacto entre un hombre y una mujer, a los que en función de su sexo se les adjudicaban distintas funciones de manera que jerárquicamente el marido ocupara una posición superior a la de la esposa. Una unión heterosexual e indisoluble, que dejaba al margen de la legalidad y la moralidad cualquier otro tipo de unión ${ }^{26}$.

El matrimonio era un rito de paso fundamental en la vida, en la que se veían implicadas no sólo la familia sino también la comunidad, que participaba del acontecimiento, pero que mientras para el hombre suponía alcanzar la verdadera mayoría de edad, para la mujer, que pasaba de estar bajo la patria potestad del padre a la del marido, se trataba en ocasiones de una pérdida de atribuciones y libertad personal, ya que a partir de entonces su vida estaba supeditada a la de su marido y los hijos que debía tener, dejando en un segundo plano cualquier otra inquietud o deseo individual ${ }^{27}$.

Los matrimonios, normalmente, respondían a estrategias familiares, en los que se buscaban el ascenso social, o el enriquecimiento del patrimonio familiar, por lo que en la mayoría de los casos se llevaban a cabo matrimonios sin "amor", tal y como se entiende hoy en día, aunque todos los tratadistas de la época aconsejaban que los esposos estuvieran bien avenidos y se profesaran afecto, algo que influiría beneficiosamente en la vida conyugal. Lo cierto es que al relegarse el componente afectivo en

25 Sobre la correspondencia con la familia Borja se puede ver: MorTE Acín, A.: "Un epistolario inédito: la correspondencia entre Sor María de Ágreda y la familia Borja (1628-1665)", en ColÁs Latorre, G. (coord.): Estudios sobre el Aragón Foral, Zaragoza, Mira Editores, 2009.

26 Gaudemet, J.: El matrimonio en occidente, Madrid, Taurus, 1993; Morant, I.: Discursos de la vida buena. Matrimonio, mujer y sexualidad en la literatura humanista, Madrid, Cátedra, 2002; MoRANT, I. y Bolufer, M.: Amor, matrimonio y familia, Madrid, Síntesis, 1998.

27 López-Cordón, Ma . V.: "Familia, sexo y género en la Edad Moderna", en Studia Histórica, Historia Moderna, vol. 18, 1998., p.109. 
las uniones matrimoniales, es fácil suponer que abundaran los conflictos en el seno de las familias y los problemas de convivencia fueran frecuentes ${ }^{28}$.

En nuestro caso, contamos con el relato sobre dos mujeres maltratadas por sus maridos que buscaron refugio en el convento. Aunque no sea un número elevado no quiere decir que no hubiese más casos de los que no se habla en el proceso. La riqueza de detalles en la descripción y las diferencias sociales que existían entre ambas mujeres nos parece ya de por sí significativo, además de que el tono en el que se relatan ambos casos, deja traslucir que no era algo inusual, sino reflejo del alto grado de violencia en el que vivía esta sociedad ${ }^{29}$.

En general, los moralistas de la época reprobaban el castigo físico a la esposa, aunque sólo en los casos en que fuese desproporcionado o brutal. Sin embargo, se admitía sin demasiados problemas como medida de corrección de mujeres díscolas o que no cumplían con su papel de esposas adecuadamente. Azotar moderadamente estaba socialmente bien visto, aunque debía evitarse en la medida de lo posible, ya que alteraba el orden armonioso deseable dentro de la familia, siguiendo el mismo criterio aplicable a los niños o los $\operatorname{criados}^{30}$.

La paciencia y la resignación eran las dos virtudes fundamentales que debía reunir una buena esposa y que le impedían, en muchos casos, oponer resistencia a los posibles abusos del marido. A pesar de que socialmente se viese con buenos ojos el castigo físico, en algunos casos los propios vecinos salieron en defensa de las mujeres que estaban siendo tratadas con brutalidad por sus maridos, como en alguno de los casos que vamos a ver a continuación, pero normalmente la mujer se hallaba desamparada ente estos episodios de violencia ${ }^{31}$.

Si la mujer contaba con recursos suficientes y con apoyo exterior podía dar el paso de pedir la separación, que sólo podía ser concedida por la Iglesia, pero los problemas de convivencia, los celos desmedidos, o el adulterio no eran motivos suficientes para conseguirla $^{32}$. Sí que se contemplaba la posibilidad de eximir a la pareja de cohabitar bajo el mismo techo, por lo que se podía llegar a una separación de hecho, mediante una "carta de apartamiento" 33 . Los llamamientos a los vicarios para que no fuesen

28 PASCUA, Ma . J. de la: "Las relaciones familiares. Historias de amor y conflicto", en MorANT, op. cit. (nota 14), p. 291; Gil Ambrona, A., Historia de la violencia contra las mujeres. Misoginia y conflicto matrimonial en España, Madrid, Cátedra, 2008.

29 Pascua, M. J.: Mujeres solas. Historias de amor y abandono en el mundo hispánico, Málaga, 1998, y Domínguez Ortiz, A.: "La mujer española en una época de crisis" en SEgurA, C. (ed.): La voz del silencio I (siglos VIII-XVIII), Madrid, A1-Mudayna, 1992. pp. 303-305.

30 Morant, op. cit. (nota 27, 2002).

31 Gil Ambrona, op. cit. (nota 28); López-Cordón, op. cit. (nota 27) p.126; Lorenzo CAdarso, P.: "Los malos tratos a las mujeres en Castilla en el siglo XVII", en Cuadernos de Investigación histórica Brocar, 15 (1989), p. 119-136.

32 Lorenzo, F.: “Actitudes violentas en torno a la formación y disolución del matrimonio en Castilla durante la Edad Moderna", en ForteA, J. I. y Mantecón, T. A.: Furor et rabies. Violencia, conflicto y marginación en la Edad Moderna, Santander, Servicio de Publicaciones de la Universidad de Cantabria, 2002, pp. $175-176$.

33 Gil Ambrona, A.: "Las mujeres bajo la jurisdicción eclesiástica: pleitos matrimoniales en la Barcelona de los siglos XVI y XVII", en BIRRIEL, M. (comp.): Nuevas preguntas, nuevas miradas. Fuentes y Documentación para la historia de las mujeres (siglos XIII-XVIII), Granada, Servicio de Publicaciones de la Universidad, 1992, pp.113-138. Morte Acín, A.: "Que si les oían reñir o maltratar el marido a la mujer la socorriesen. Familia, vecindad y violencia contra la mujer en la Edad Moderna", en Revista de Historia Moderna, Anales de la Universidad de Alicante, 30 (2012), pp. 211-228. 
especialmente receptivos a conceder la separación, y las pocas posibilidades de éxito en la obtención de la nulidad, obligaban en muchos casos a las mujeres a permanecer en sus casas, ya que la cohabitación era una obligación del matrimonio canónico, y su incumplimiento podía acarrear penas incluso de carácter civi1 ${ }^{34}$.

En el primero de los casos que se dieron en Ágreda se cuenta el caso de una mujer de "buenas prendas y sangre". La mujer se presentó en el convento por primera vez para pedir a Sor María que le ayudara a pedir a Dios sobre un problema que le atormentaba. Pasados los años, volvió a aparecer por el convento esta vez vestida con prendas de varón. La mujer temiendo que su marido la matara porque tenía celos, había huido de su casa disfrazada de hombre. Según el relato, se llegó incluso a cruzar en el camino con su esposo que había salido a buscarla con intención de matarla, y según el testimonio, gracias a la intercesión de Sor María no llegó a reconocerla ${ }^{35}$. Llegó muy alterada al convento donde se entrevistó con Sor María que se apresuró a ofrecerle ayuda. Mandó que se cerrara bien la puerta del locutorio, en el que se encontraba la mujer, para impedir que el marido pudiera entrar, y se le dio comida y ropa. Sor María escribió a D. Diego de Castejón y Fonseca, por entonces obispo de Tarazona, para que la acogiese en su casa hasta que se determinase qué se debía hacer ${ }^{36}$.

El marido llegó "colérico y furioso" al convento, y una vez que se sosegó, Sor María habló con él para intentar buscar una solución "como era tan grave el caso pasaron muchos debates de ambas partes de los parientes", hasta que Sor María dio con la mejor opción, que fue que ambos entraran en un convento. Como prueba de las infinitas virtudes de Sor María, se explica cómo el hombre no sólo atendió a razones y permitió que su mujer profesase, sino que él mismo tomó los hábitos en el convento de San Julián en la misma villa ${ }^{37}$. La solución por tanto fue la separación física de los esposos $^{38}$.

Del segundo caso se ofrecen menos detalles. Al parecer una mujer también temiendo por su vida, acudió a Sor María en busca de ayuda, y la abadesa puso en marcha un dispositivo que la protegiera, involucrando a otras personas del pueblo:

no satisfecha la sierva del Señor con los medios que había puesto para su paz, hizo que unas personas muy virtuosas, y de su satisfacción, estuvieran mucha parte de la

34 PASCUA, op. cit. (nota 29).

35 Este detalle en el relato es uno de los puntos sobre los que creemos que hay que tener reservas puesto que, el hecho de que fuese la intercesión de Sor María, la que propiciase que no fuera reconocida por el marido, otorga una funcionalidad al dato, lo que podría significar que no respondiese exactamente a la realidad. Menos sospechoso nos parece el hecho de que saliese disfrazada de casa con el objetivo de pasar más desapercibida entre la gente.

36 ASV, Congr. Riti, Proc. 3206, testimonio de Sor Isabel María de la Cruz.

37 ASV, Congr. Riti. Proc. 3206, f.192r-v. Testimonio de Sor Ángela María de San Bernardo, y f. 222v.

38 En el caso de que una mujer presentara una demanda de separación, existía la posibilidad de llevar a cabo el "secuestro de la esposa" por medio de la autoridad eclesiástica, lo que suponía mantener en una "casa honrada y segura" a la mujer hasta que se resolviera el contencioso, como medida de protección. Esta "casa" podía ser la casa de familiares o un convento. En ocasiones cuando el proceso se alargaba o como vía intermedia de solución del conflicto, el "secuestro" se podía alargar a perpetuidad. Lo que podría haber ocurrido en este caso. Gil AmBrona, op. cit. (nota 28), p. 130. 
noche en centinela cerca de su casa para que si les oía reñir o maltratar el marido a la mujer la socorriesen ${ }^{39}$.

No tenemos noticia de cómo terminó este caso porque en el proceso ya no se ofrecen más datos acerca de si la mujer siguió en el domicilio conyugal o también para ella, como en el caso anterior, se buscó un lugar donde viviera apartada de su marido.

Asimismo, gracias o a causa de la separación matrimonial, se produjo la entrada en el convento de Ágreda de dos mujeres, aunque en estos casos no tenemos constancia de que la separación se produjese por problemas relacionados con la violencia. La primera de ella es Sor María Antonia de Jesús, en el siglo Doña María Coronel. Antonia era hija de un primo hermano de Sor María, y dentro del convento desempeñó la labor de secretaria de Sor María, lo que le permitió tener un conocimiento mucho más profundo de la abadesa. Fue la esposa de Don Francisco de Echarri, hasta que se separaron y ambos entraron en religión, uno como canónigo de la catedral de Tarazona y la otra como religiosa en el convento de Ágreda ${ }^{40}$. Sor Antonia entró en el convento a la edad de veintiséis años, y había contraído matrimonio a los trece ${ }^{41}$.

El segundo caso es el de Sor Teresa María de Jesús, llamada en el siglo Doña Teresa de Aranda, natural de Jaca, que en el momento de declarar decía tener 52 años. ${ }^{42}$ Afirma Sor Teresa, que antes de entrar en el convento mantuvo relación epistolar con Sor María durante más de 15 años y fue a visitarla en tres ocasiones. La primera desde Zaragoza, la segunda desde Madrid y la tercera desde Badajoz. Cuando, viviendo en Zaragoza, Teresa tuvo conocimiento de la fama de santidad de Sor María sintió un gran deseo de conocerla y de compartir con ella sus deseos y preocupaciones, y es que según relata Teresa, desde niña había sentido el anhelo de ser religiosa, pero por la presión familiar había acabado contrayendo matrimonio. Un matrimonio en el que no parece que fuera feliz, aunque no llega a especificar las causas.

Ya en su primera visita expuso a Sor María su deseo de profesar y lo difícil de alcanzar el objetivo dado su estado civil. En la relación epistolar, Sor María, siempre según el testimonio de Teresa, le animaba a mantener vivo el deseo en su interior y a confiar en que Dios acabaría por disponer que su ansiada voluntad se cumpliese. Finalmente, Teresa consiguió su meta y en su última visita a Ágreda desde Badajoz, alrededor de 1659, se quedó allí, entrando sus cuatro hijas también en religión y dejando en Badajoz a su marido y a un hijo. En una carta que Don Martín de Herrera, esposo de Sor Teresa, envió a Sor María en abril de 1660, explica cuál era la situación del matrimonio y las razones de que, en principio, se hubiera mostrado reacio a dar la autorización a su mujer para entrar como religiosa en el convento, cuando ella se lo había solicitado algún tiempo antes. Según explica Don Martín, él en aquellos

39 ASV, Congr. Riti. Proc. 3206, testimonio de Sor Isabel María de la Cruz, f. 221r.

40 En una carta dirigida a D. Diego Castejón, obispo de Tarazona, de 15 de julio de 1645, Sor María le pide que inste a D. Francisco de Echarri a que se ordene y acuda a la profesión de Sor Antonia. Le persuada $V$. Ilma. que se ordene y venga a la profesión de su mujer, que después puede continuar con sus pleitos. Y para que esta obra se haga con perfección conviene sea a un tiempo el ordenarse y la profesión. En la siguiente carta, de 29 de julio de 1645, le agradece las gestiones que ha hecho y le pide además que vaya a ordenar a su sobrina. Archivo Concepcionistas Ágreda (ACAgr.) 1652. caja 24, carp. 91.

41 ASV, Congr. Riti, Proc. 3206, testimonio de Sor María Antonia de Jesús, f. 165v.

42 Ibidem, testimonio de Sor Teresa María de Jesús, f. 327r-334v. 
momentos no podía entrar en religión aunque lo deseaba vivamente, por tener que dar cuenta del oficio que había desempeñado durante quince años y que pretendía traspasar a su hijo, por lo que según sus palabras:

la mayor (fuerza) para mi era la reputación, que tengo calidad para no deslucirla. El no haberle dado licencia antes no convenía, pues vuelta a Madrid Su Magestad el Rey le pudiera yo dar el oficio a mi hijo [...] con que (entonces) no era con la seguridad que ahora que están ya todos los hijos acomodados ${ }^{43}$.

Sin embargo, el principal motivo de la carta de Don Martín era dejar claro al convento, (que parece ser que tenía dudas acerca de si Teresa contaba con la licencia de su marido), que la licencia existía y había sido firmada ante el obispo de Badajoz, pero que no se había ejecutado antes por los motivos que había expuesto ${ }^{44}$. De nuevo una separación matrimonial, en este caso parece de mutuo acuerdo, se resolvía con la entrada en religión de uno de los miembros, en este caso de la mujer. Pero Teresa, hay que destacar además, no dudó en dejar atrás a su marido y a su hijo, y no esperó a obtener la licencia de su esposo para cumplir su deseo, lo que le ocasionó alguna dificultad en el convento con los trámites burocráticos para cuya resolución necesitó y obtuvo la ayuda de su esposo ${ }^{45}$.

Sor María también actuó en problemas matrimoniales de diferente naturaleza. En el caso que vamos a relatar, los problemas vinieron de las disputas entre dos familias tras el matrimonio de los hijos. La funcionalidad del matrimonio, tanto como cauce de procreación, en una sociedad permanentemente preocupada por la supervivencia, como en su vertiente socioeconómica, condicionaba las circunstancias y las premisas bajo las que debía producirse la unión. El Concilio de Trento se ocupó largamente del matrimonio para codificar el marco en el que debía tener lugar. Uno de los conceptos sobre el que existía consenso era el de "el matrimonio entre iguales", pero que en ocasiones no era respetado, ya que los contrayentes llevaban a cabo matrimonios clandestinos, sin el conocimiento ni el consentimiento paterno, siendo en muchos casos uniones desiguales ${ }^{46}$.

La solución no era fácil ya que la Iglesia pretendía mantener el principio de libertad de los esposos para aceptar el matrimonio, lo que chocaba con el interés de las familias de intervenir en la negociación de las uniones conyugales, asegurándose de que cumpliesen con la función socioeconómica a la que hemos hecho referencia.

En Trento se optó por mantener la necesidad de que los novios acudiesen libremente al matrimonio, pero para evitar las uniones clandestinas, era obligatorio que se celebrase públicamente con la presencia de testigos, bendición sacerdotal y las amonestaciones oportunas, lo que permitía a las familias un margen de maniobra,

\footnotetext{
43 ACAgr., 164.

44 Ibidem, testimonio de Sor Teresa María de Jesús, f. 330r.

45 Dadas las dificultades que existían para conseguir una separación legal, se daban los casos en los que uno de los cónyuges abandonaba directamente el hogar. En el caso de las mujeres, este comportamiento era duramente perseguido por lo que de trasgresión de las normas sociales suponía, llegando incluso a la excomunión de la mujer, por lo que para comenzar una nueva vida, era necesario despejar las dudas sobre que el alejamiento del hogar no se había hecho sin el consentimiento del marido. Gil AmBronA, op. cit. (nota 28).

46 Pascua, op. cit. (nota 29).
} 
de manera que continuaron pudiendo decidir, en la mayoría de los casos, con quien casaban a sus hijos. ${ }^{47}$

En Castilla, la legislación ya recogía, con anterioridad a Trento, el libre consentimiento como requisito imprescindible para la validez del matrimonio, lo que no significaba poder casarse con quien se quisiera sino poder negarse a uno impuesto, pero también era obligatorio el consentimiento paterno, por lo que esta cuestión se convirtió en motivo de disputa tras entrar en vigor lo acordado en Trento. Como vía intermedia se optó por mantener la necesidad de la aprobación paterna, ya que se entendía que era un medio de evitar tanto matrimonios desiguales como los que fueran consecuencia de la seducción de las jóvenes ${ }^{48}$.

El caso del que nos ocupamos se enmarca en esta problemática, la de los matrimonios acordados, e introduce además la cuestión de la palabra de matrimonio. Se entendía que era el primer paso para la unión conyugal, y el incumplimiento de este acuerdo estaba penado tanto por el derecho eclesiástico como por el civil ${ }^{49}$. El testimonio lo ofrece Don Miguel Pasquier de Camargo, del que ya hemos hablado anteriormente, al narrar lo que le ocurrió a su hijo en vísperas de su boda. Al parecer Doña María Teresa Herrera de Angulo, había manifestado su voluntad de casarse con el hijo del testigo, Don José Pasquier, y cuando padre e hijo iban a dirigirse a casa de la familia de la novia para hacer oficial el compromiso, la madre, que al parecer no estaba de acuerdo con el matrimonio, se llevó por la fuerza a su hija, a "algún lugar fuera del obispado", con el fin de casarla con otro caballero. Teresa tuvo tiempo de poder avisar a la familia de José de lo que estaba ocurriendo, y José, su padre y otros caballeros salieron a buscarla. Tal y como señala el testigo "habiendo llegado al lugar donde estaba dicha Doña María Teresa con su madre y tía, y otra mucha gente, habiendo habido muchos disturbios, y contradicciones, se serenaron las materias de tal manera, que la dicha Doña María Teresa declaró su voluntad, y su madre y parientes vinieron en ello".

Así pues, la boda se celebró con armonía entre las familias, de lo que Sor María fue informada, ya que había estado al tanto de todo lo ocurrido. Sin embargo, la religiosa anunció que aunque pareciese que todo iba bien, no debían fiarse porque las dificultades aparecerían de nuevo. Así sucedió, y al parecer una persona que gozaba de la confianza de Don Miguel, se puso de parte de la familia de la novia, azuzando las discusiones y rencillas que habían surgido antes de la boda, lo que enquistó el conflicto entre las dos familias de modo que "los irritó sembrando discordias, que duraron muchos años, y llegando las pesadumbres a termino de desafíos".

Sor María actuó como intermediaria entre las dos familias limando las asperezas y tratando de que la vida del joven matrimonio discurriese con normalidad. La poderosa presencia de Sor María en la villa de Ágreda le otorgaba un prestigio que le permitía erigirse, en casos como este, como consejera de las personas que entraban en conflicto siendo respetada su opinión ${ }^{50}$.

47 GAudemet, op. cit. (nota 26), p. 402.

48 López-Cordón, op. cit. (nota 27), p.124.

49 Pascua, op. cit. (nota 29), p. 306.

50 La figura de mujeres con prestigio que actuaban impartiendo justicia a manera de "árbitras" ha sido estudiada por García Herrero, C.: Del nacer y el vivir. Fragmentos para una historia de la vida en la Baja Edad Media, Zaragoza, I.F.C., 2005, pp. 353-383. 
No sólo eran los problemas de salud y maritales los que impulsaban a la población a visitar el convento. También acudían en busca de ayuda personas con dificultades económicas, a veces, por lo que se desprende de los testimonios, en situaciones desesperadas. Al respecto, hemos seleccionado un caso que nos parece ilustrativo, porque en él se muestran algunas claves que nos parecen significativas sobre cómo era la vida para una buena parte de la población.

Un pobre hombre carbonero por buena dicha suya, trajo carbón al convento de la Venerable Madre, y entró en él y habló con las porteras muy despechado, porque tenía muchos hijos y grande pobreza, hallándose imposibilitado de socorrerlos. Movidas de compasión, las porteras pidieron a la sierva del señor le consolase, porque ellas no podían y temían según estaba de afligido se había de desesperar, y con su acostumbrada piedad le habló y consoló y le dio por limosna un par y uno Real de a ocho, y muy alentado se fue y ha asegurado algunas veces que volvió al convento, $[. .$.$] que desde$ que le dio lo referido no le ha faltado lo necesario para su mujer y sus hijos, ni dinero, y dice que (Sor María) sentía mucho las pechas que tienen los pobres, y que decía que de gente justa y necesitada había visto muchos tentados de desesperación por el ahogo de su necesidad y el aprieto en que muchas veces se veían para pagar y así escribió al Rey nuestro Señor D. Felipe Quarto, que aliviase a los pobres de tales cargas ${ }^{51}$.

Como hemos señalado, los testimonios recogidos en el proceso buscaban ensalzar la figura de Sor María y por ello hay que mantener ciertas reservas sobre lo que en ellos se dice. Pero, sí es cierto que las dificultades económicas de los "pecheros" durante aquellos años de crisis económicas existieron, y que en la realidad más cercana a Sor María debieron darse casos que ella conociera. No hay que olvidar que en algunas cartas a Felipe IV tocó el tema de los impuestos y las cargas fiscales excesivas para la población con menos recursos económicos ${ }^{52}$.

Hasta el convento se acercaron, del mismo modo, personas con problemas que les habían llevado a la exclusión social, como casos de alcoholismo. Estas personas trataban de encontrar con la ayuda de Sor María una cura a su dependencia y sus casos también nos son relatados con profusión de detalles, que ilustran las dificultades por las que pasaban estos sujetos tanto en su vida familiar como por el rechazo que sufrían por parte de la sociedad.

Miguel Zordia, labrador, natural y vecino de la ciudad de Arnedo, de 50 años de edad da su testimonio acerca de sus problemas con el alcohol y cómo los solucionó gracias a la ayuda de Sor María ${ }^{53}$. Comienza explicando cuál era su situación antes de acudir a Ágreda:

hallándose este testigo con grande trabajo y achaque tal que bebiendo aunque no fuera sino media escudilla de vino le hacía tanto daño que perdía el sentido, de suerte

51 Ibidem, ASV, Congr. Riti, Proc. 3206, testimonio de Sor Isabel María de la Cruz, f. 225r.

52 Sobre las dificultades económicas que los "pecheros" atravesaron en aquellos momentos puede verse: Domínguez Ortiz, A.: Politica y hacienda de Felipe IV, Madrid, Edit. Derecho Financiero, 1960; Gelabert, J.: "La bolsa del rey y la vida de los súbditos 1550-1650”, en Estudis, 29, (2003), pp. 7-20.

53 Ibidem, testimonio de Miguel Zordia, f. 17v. 
que no era dueño de sus acciones, mas antes hacía grandes disparates con su mujer e hijos [...] porque la pasión que tenía por beber era grandísima.

Debido a su alcoholismo no podía trabajar ni encargarse de su casa, "era despreciado por todos y aún sus deudos le deseaban la muerte". Gracias a un vecino de Arnedo que había visitado a Sor María por un problema en la vista y que había obtenido muy buenos resultados, se decidió a acudir también él al convento agredano. Cuando llegó allí se entrevistó con Sor María, le explicó su situación y la religiosa se apresuró a ofrecerle ayuda. Le hospedó durante seis días en la casa de los criados, dándole de comer y hablando con él, en una especie de cura de desintoxicación, pasados los cuales comenzó el camino de vuelta a casa. Ya desde el primer momento pudo experimentar un gran cambio en su comportamiento:

llegando cerca de una taberna donde se vendía vino, le dio olor del vino y le ofendió tanto que el olor le revolvió el estómago y le dio un gran horror y no se atrevió a pasar por aquella calle,

y termina su testimonio afirmando que desde aquel día, del que ya habían pasado dieciséis años, no había vuelto a probar el vino, lo que había contribuido a que pudiera recuperar sus relaciones familiares y vecinales y que todo ello había sido "gracias a Dios que por intercesión de Sor María había obrado en él dicha tan grande".

Aún existen al menos dos testimonios más de un hombre y una mujer a los que Sor María, de diversos modos, había ayudado a dejar su adicción al alcohol, bien por medio de reliquias, de oraciones o de terapias de desintoxicación como en el caso que acabamos de relatar $^{54}$.

Los temas referidos a la salud, a la economía familiar, a las relaciones personales y a la exclusión social eran los que preocupaban en su vida cotidiana a los habitantes de Ágreda. Ni las guerras en Europa, ni los oropeles de la corte tenían para ellos más importancia en su vida que el sobrevivir en una sociedad dura y difícil para las personas que se encontraban en situaciones de debilidad por la razón que fuese. Por ello, la presencia en Ágreda de alguien que diera respuesta a sus problemas era lo que realmente hacía de Sor María el punto de referencia al que dirigirse, despertaba su admiración y fue lo que, en última instancia, les impulsó a declarar en su proceso de beatificación.

La fama de santa que acompañaba a Sor María y que la orden franciscana se había encargado de potenciar, la dotaba de prestigio suficiente como para ser considerada por sus vecinos como alguien cuyo buen juicio había que tener en cuenta y podía servir para resolver sus conflictos. Sor María era así la depositaria de cierto grado de autoridad que la convertía en una persona de relevancia y reputación de sabia en su comunidad.

54 Ibidem, testimonio de D. Antonio Muñoz Serrano, f. 22r. 